Epigenetic dynamic during endochondral ossification and articular cartilage

\title{
development
}

Lyess Allas ${ }^{1}$, Karim Boumédiene ${ }^{1}$, Catherine Baugé ${ }^{1}$

${ }^{1}$ Normandie Univ, UNICAEN, EA7451 BioConnecT, Caen, France

\# Address for correspondence:

Catherine BAUGE

BioConnecT

Université de Caen Normandie

14032 CAEN

FRANCE

Phone : +33 (0)2 31068218

E-mail : catherine.bauge@ unicaen.fr 


\begin{abstract}
Within the last decade epigenetics has emerged as fundamental regulator of numerous cellular processes, including those orchestrating embryonic and fetal development. As such, epigenetic factors play especially crucial roles in endochondral ossification, the process by which bone tissue is created, as well during articular cartilage formation. In this review, we summarize the recent discoveries that characterize how DNA methylation, histone posttranslational modifications and non-coding RNA (e.g., miRNA and lcnRNA) epigenetically regulate endochondral ossification and chondrogenesis.
\end{abstract}


Epigenetic is the study of reversible changes in gene expression transmitted during cell divisions that do not result from DNA sequence modification. The epigenome includes DNA methylation, post-translational histone modifications which induce changes in chromatin structure, as well as non-coding RNA expression ${ }^{(1)}$. According to its condensation state, chromatin permits or prevents the access of the transcriptional machinery to DNA sequences. Epigenetic marks are established by proteins called "writers", such as DNA methyltransferases (DNMT), histone acetyltransferases (HAT), and histone methyltransferases (HMT), whereas they are removed by proteins known as "erasers", especially histone deacetylases (HDAC), histone demethylases (KDM) and DNA demethylases (TET). They are interpreted by transcription factors and cofactors referred to as "readers". Non coding RNA (ncRNA) also act as epigenetic regulators by controlling DNA transcription, RNA maturation and translation. As developed in this review, many epigenetic actors and chromatin remodeling complexes regulate endochondral ossification as well as cartilage development. Epigenetic processes are also major mediators in joint disease development. However, this role in joint diseases has been well-documented elsewhere these last months ${ }^{(2-5)}$.

\section{Endochondral ossification}

The mechanical integrity of the skeleton is imparted primarily by two tissues: bone and cartilage. During development, cells from different embryonic origins undergo a similar sequence of events to form fetal skeletal cartilage ${ }^{(6)}$. The paraxial mesoderm gives rise to the sclerotome, a developmental structure that will pattern the vertebrae and ribs of the axial skeleton. In contrast, the lateral flank mesoderm generates the limb bud that patterns long bones of the limbs. Endochondral ossification contributes in part to formation of the craniofacial bones, including the cranial base, mandible and temporal bones. 
In each case, development of skeletal elements begins with cellular condensations. Cells this process, mesenchymal chondroprogenitor cells aggregate. The expression of cell adhesion molecules increases. These changes in cell behavior are tightly regulated by activation of chondrocyte-selective transcription factors, particularly, the transcription factor Sex Determining Region Y-Box 9 (SOX9). Sox9 is expressed very early in the development and is the major regulator of the chondrogenic program ${ }^{(8)}$.

Cells at the core of condensations change in morphology from fibroblast-like to more spherical, and increase the synthesis of specific extracellular molecules, including aggrecan and collagens type II, IX and XI. This is mediated though the transcription factor trio SOX5/6/9. At the same time, cells at the periphery of condensation retain a fibroblastic morphology and differentiate into perichondrial cells that continue to express type I collagen (6)

Chondrocytes at the core of the condensations quickly proliferate to promote limb extension and linear growth of the developing skeleton. Next, they stop to proliferate and undergo progressive hypertrophy. This final step of differentiation is a well-coordinated program that is governed, in part, by the transcription factor runt-related transcription factor 2 (RUNX2) ${ }^{(8)}$. This ordered process of proliferation and differentiation leads to the formation of stratified zones of cells at different cell cycle stages ${ }^{(7)}$ (figure 1). At the extremity of the elements, in the resting zone, chondrocytes exhibit a round cell morphology and are quiescent, whereas chondrocytes in the columnar or proliferative zone have a more flattened morphology and rapidly proliferate. Then, towards the core of the elements is a zone of post-mitotic cells that begin to enlarge and are characterized by the expression of Indian Hedgehog (IHH) and decreased expression of SOX9. This is the prehypertrophic zone. Finally, the hypertrophic zone represents terminal, enlarged chondrocytes that produce a unique mineralized 
extracellular matrix (ECM) containing type X collagen. Hypertrophic chondrocytes also produce matrix metallopeptidase 13 (MMP13) and vascular endothelial growth factor (VEGF) to facilitate matrix remodeling and vascular invasion. This invading vasculature permits the entry of osteoprogenitors that differentiate into osteoblasts. Hypertrophic chondrocytes undergo apoptosis ${ }^{(9,10)}$; thereby, cartilage serves as a template and is replaced by bone during endochondral ossification.

\section{Articular cartilage formation and maintenance}

Articular cartilage plays an important role in withstanding mechanical stress associated with joint movement at the ends of long bones. It differs from growth plate cartilage in terms of extracellular matrix content, cellular organization and mechanical properties. Articular cartilage is comprised primarily of ECM, composed mainly of collagens and proteoglycans, populated sparsely with chondrocytes that perform matrix-generation and maintenance functions (figure 2). Mature articular cartilage has a zonal organization that is divided into a superficial layer, a mid layer, the deep layer, and the calcified layer, in order from the surface of articular cartilage toward the bone.

During skeletal patterning, articular cartilage formation begins at the interzones, regions of undifferentiated mesenchyme that separate developing skeletal elements. The interzone is also the presumptive joint formation site ${ }^{(11)}$. This suggests that articular "stable" chondrocytes may have a distinct embryonic origin compared to the "transient" chondrocytes that derive from the mesenchymal condensations forming the bulk of anlagen ${ }^{(12)}$. Interzones first appear as densely cellular, homogenous regions. As joint development progresses, the interzone derives three layers: two chondrogenic layers that cover the articular surfaces of the developing opposed skeletal elements, and an intermediate layer that separates them. Some evidences suggests that the cells derived from this intermediate layer differentiate to become 
articular chondrocytes, whereas the outer layer chondrocytes are incorporated into the growing epiphysis ${ }^{(11,13)}$.

Transient growth cartilage and articular cartilage differ in their collagen composition during development. In embryonic growth cartilage, collagen type-IIA expression precedes production of collagen type-IIB, which is not detectable at later stages of development. In contrast, in articular cartilage collagen type-IIA protein is not produced within the interzone, which reinforces the belief that the cartilage anlagen that forms individual skeletal elements is not continuous ${ }^{(14,15)}$.

Other substantial differences exists between articular chondrocytes and transient chondrocytes. Contrary to growth plate chondrocytes, articular chondrocytes maintain a stable phenotype characterized by small cell size, and they do not undergo a sequence of proliferation, maturation, hypertrophy, apoptosis and ossification ${ }^{(11)}$. Also, they maintain joint function throughout life and do so by retaining a stable and permanent phenotype, producing all the macromolecular components of articular cartilage including aggrecan and collagen II, and providing the tissue with functional resilience.

However, in pathological conditions, articular chondrocytes can potentially undergo maturation and hypertrophy, and display traits of transient growth plate chondrocytes. This shift from a permanent to a transient chondrocyte phenotype is seen for instance in the joints of osteoarthritic patients ${ }^{(12)}$. Traits expressed by such abnormal articular chondrocytes include an enlarged hypertrophic cell size, increased production of metalloproteases (such as MMP13), and expression of hypertrophic genes, such as alkaline phosphatase or type $\mathrm{X}$ collagen. These aberrant characteristics are associated with joint dysfunction and disease.

These processes of endochondral ossification and articular cartilage formation are highly organized and tightly controlled. In particular, as we will discuss in this review, epigenetic 
regulations plays crucial roles in this orchestration. This includes DNA methylation, histone post-translational modifications (acetylation, methylation) and non-coding RNA.

\section{DNA methylation}

DNA methylation is the addition of a methyl group to the DNA, at $\mathrm{CpG}$ dinucleotides to convert cytosine to 5-methylcytosine $(5 \mathrm{mC})$. DNA methylation favors genomic integrity and largely contributes to gene silencing ${ }^{(16)}$.

DNA methylation patterns are established and modified in response to environmental factors by three DNA methyltransferases (DNMT), named DNMT1, DNMT3A and DNMT3B. DNMT1 is a maintenance methyltransferase that methylates hemi-methylated DNA (one strand). It is therefore important for transferring patterns of methylation to a newly synthesized strand after DNA replication. DNMT3A and DNMT3B are de novo methyltransferases, which add methylation to unmethylated cytosines ${ }^{(1)}$.

While embryonic regulation of genomic DNA methylation is crucial and relatively well documented during the early stages of development, less is known about its involvement during endochondral ossification and chondrogenesis. DNA methylation is an essential step by which embryonic stem cells silence several key transcription factors, such as SOX2, octamer-binding transcription factor 3/4 (OCT3/4), and Nanog homeobox (NANOG) ${ }^{(17-19)}$, and partial disruptions of the DNA methylation machinery by genetic mutations often cause serious developmental defects ${ }^{(20-23)}$; however, its role in cartilage and/or in chondrocytes is unclear.

An early study using chick embryos reported the possible role of DNA methylation in the regulation of type I and II collagen genes during chondrocyte differentiation and dedifferentiation ${ }^{(24)}$; however, the methylation status of promoter $\mathrm{CpG}$ islands was found to 
be preserved in critical genes, such as SOX9 and RUNX2, during chondrogenesis ${ }^{(25)}$. This observation may indicate a retained capability of the mesenchymal progenitor cells to change their differentiation status even after chondrogenesis, since similar observations about adipogenesis of MSCs have been reported ${ }^{(26-29)}$. In contrast, two CpG sites within the COL10A1 promoter appear to be demethylated during chondrocyte differentiation from mesenchymal stem cells correlating with COL10A1 expression ${ }^{(30)}$.

Recently, using genetically modified murine models, DNMT3B has been identified as a critical epigenetic factor in the regulation of articular chondrocyte differentiation and in the maintenance of articular cartilage homeostasis ${ }^{(31)}$, as well in the regulation of chondrocyte hypertrophic differentiation ${ }^{(32,33)}$.

Additional insight has been demonstrated using potent demethylation agents, especially 5azacytidine (5-azaC) and 5-aza-2'-deoxycytidine (5-aza-dC). Pretreatment of mesynchymal stem cells with 5-azaC facilities osteogenic differentiation, causing hypomethylation of genomic DNA and increased gene expression ${ }^{(34,35)}$. Furthermore, 5 -azaC promotes terminal differentiation of articular chondrocytes ${ }^{(36,37)}$ by acting as a modulator of chondrocyte hypertrophy and maturation in cultured chick caudal region chondrocytes ${ }^{(38)}$.

Methylated cytosines $(5 \mathrm{mC})$ can be further oxidized to 5-hydroxymethylcytosines $(5 \mathrm{hmC})$ by Ten-eleven-translocation (TET) proteins ${ }^{(39-41)}$, leading to either a stable 5 hmC gain, or further oxidation to 5-formylcytosines (5fC) and 5-carboxylcyosines (5caC) and DNA demethylation. 5hmC acquisition appears to play a major regulatory role in cartilage differentiation and development ${ }^{(42)}$. Changes in $5 \mathrm{hmC}$ levels have been reported during limb development, and global $5 \mathrm{hmC}$ levels increase during both in vitro and in vivo chondrogenesis. Interestingly, stable gains in $5 \mathrm{hmC}$ were observed in specific subsets of genes including genes associated with cartilage development and in chondrogenic lineagespecific genes, such as SOX5, 6 and 9, as well as COL2A1, whereas minimal changes were 
observed in the housekeeping genes HPRT (Hypoxanthine guanine phosphoribosyl transferase) and beta-actin ${ }^{(42)}$. Additionally, gene expression changes in Tet family members, TET 1, 2 and 3, demonstrate a similar pattern during chondrogenic differentiation, with an initial increase followed by a decline in TET expression. Moreover, knockdown of TET1 leads to both decreased $5 \mathrm{hmC}$ levels and impaired in vitro chondrogenic differentiation $(42)$.

\section{Histone acetylation}

RUNX2 and SOX9 are often referred to as master regulators of osteoblast and chondrocyte lineage commitment, respectively. These transcription factors bind DNA and provide docking sites for transcriptional co-activators and repressors, including histone deacetylases (HDAC) and their enzymatic counterparts, histone acetyl transferases (HAT), permitting a tissuespecific gene expression regulation ${ }^{(43)}$.

The HAT writers add a negatively charged acetyl groups $(\mathrm{CH} 3 \mathrm{CO})$ to $\varepsilon$-amino groups of lysine residues in the $\mathrm{N}$-terminal histone tails to neutralize the positively charged sidechains. This reduces the affinity of histones for negatively charged DNA, and thereby favors chromatin decompaction, facilitating the access of the transcriptional machinery to DNA target sequences. Conversely, by erasing acetyl groups, HDACs favor chromatin condensation and transcriptional repression. HDACs can also deacetylate lysine residues on non-histone proteins, including RUNX2, affecting their stability and/or cellular localization to influence gene expression programs ${ }^{(43,44)}$.

In human, HDACs are subdivided into four classes. Classical HDACs, comprise class I, II and IV and have a zinc dependent activity, while class III (sirtuins, SIRT) are nicotinamide adenine dinucleotide $\left(\mathrm{NAD}^{+}\right)$dependent. Class II HDAC (HDAC4-9 and 10) demonstrate a 
more tissue restricted expression pattern than class I HDAC (HDAC 1-3 and 8), making them important contributors to cell-specific differentiation programs.

The roles of HDACs in the first step of endochondral ossification are difficult to ascertain because many HDAC knock-out mice die during early embryogenenis (table 1). However, HDAC2/4/5/6/8 and 9 do not appear to regulate mesenchymal condensation because individual deletion of these enzymes allows early endochondral bone formation ${ }^{(45-47)}$. But it cannot be excluded that some redundancy exists amongst these HDACs in regulating the endochondral ossification process, as is the case for HDAC5/9 that compensate during heart development ${ }^{(45)}$.

More is known about the functions of HDACs within subsequent phases of endochondral ossification. During commitment of mesenchymal precursors to the chondrocyte lineage, HDAC1 associates with $\mathrm{Nkx3.2,} \mathrm{one} \mathrm{of} \mathrm{major} \mathrm{transcriptional} \mathrm{repressors} \mathrm{governing} \mathrm{cartilage}$ formation during endochondral ossification ${ }^{(48,49)}$. This complex also represses Smaddependent signaling to control BMP2 responses ${ }^{(50)}$. During the following stages, HDAC1 regulates expression of chondrocyte specific matrix genes including aggrecan, collagens (type II and IX) and COMP ${ }^{(43)}$. HDAC2, highly homologous to HDAC1, also regulates the expression of cartilage ECM genes (aggrecan, collagen type II and XI) ${ }^{(51)}$. A role for HDAC1 during bone formation was also supported by the differential expression of HDAC1 during osteoblast differentiation. Indeed, its expression decreases during osteoblast differentiation, whereas its knock-down stimulates osteoblastic differentiation ${ }^{(52)}$. Mechanistically, HDAC1 regulates osteoblast differentiation through a physical association with RUNX2 to decrease transcriptional activity and to repress the stimulatory effects of p300 ${ }^{(52)}$.

HDAC3 and HDAC4 control chondrocyte hypertrophy. HDAC3 is highly expressed in resting and prehypertrophic growth plate chondrocytes, as well as in articular chondrocytes ${ }^{(43)}$. Conditional deletion of HDAC3 in osteo-chondroprogenitor cells decreases growth plate 
height, and expands the hypertrophic zone ${ }^{(53)}$. HDAC3-deficient chondrocytes enter in hypertrophy sooner, exhibit increased expression of cytokine and matrix-degrading genes (IL6, MMP3, MMP13) and a reduced abundance of genes related to extracellular matrix production, bone development, and ossification (aggrecan, collagen type II and X, IHH, osteopontine) ${ }^{(54-56)}$.

The expression pattern of HDAC3 partially overlaps with that of HDAC4, which is also required for proper endochondral ossification ${ }^{(47)}$. Both control chondrocyte hypertrophy through their interaction with the key transcription factors RUNX2 and MEF2, as well as with corepressor ZPF521 ${ }^{(47,53,57)}$. However, unlike HDAC3, HDAC4 expression is maintained in hypertrophic chondrocytes, and mice with germline deletion of HDAC4 function are viable, but exhibit premature endochondral ossification ${ }^{(47)}$. Thus, genetic deletion of HDAC4 causes premature ossification and accelerated chondrocyte hypertrophy, as evidenced by increased expression of IHH, RUNX2 and collagen type X within the developing growth plate ${ }^{(47)}$. In contrast, HDAC4 overexpression in vivo mimics the RUNX2 KO phenotype and results in inhibition of endochondral ossification ${ }^{(47)}$. HDAC4 also regulates osteoblast maturation by controlling expression of MMP13 through a RUNX2-dependent and PTH-sensitive mechanism ${ }^{(58)}$. Also, BMP signaling facilitates nuclear export of HDAC4, impeding its ability to bind and repress nuclear transcription factors like RUNX2 ${ }^{(59,60)}$. Recently, it was highlighted that mitogen-activated protein kinase p38 (p38 MAPK) increases caspasedependent HDAC4 degradation and consequently induces RUNX2 expression as well as hypertrophic differentiation ${ }^{(61)}$.

Less is known about the role of other HDACs in endochondral ossification, but numerous HDACs regulate or interact with RUNX2. HDAC5, like HDAC4, is expressed in mature osteoblasts ${ }^{(62)}$. It regulates TGF- $\beta$-dependent signaling and downstream gene repression in osteoblasts through an interaction with a RUNX2/SMAD3 complex ${ }^{(62)}$. HDAC6 is expressed 
in differentiated osteoblasts, binds RUNX2 to repress gene expression, but is also rapidly bone density ${ }^{(64)}$. HDAC7 also inhibits the activity of RUNX2 and slows osteoblast maturation ${ }^{(59)}$. In addition, HDAC7, which is highly expressed in proliferating cells within the growth plate, suppresses chondrocyte proliferation and $\beta$-catenin activity during endochondral ossification $^{(65)}$.

HDAC class III members, called sirtuins, are structurally distinct from class I and II HDACs. They are $\mathrm{NAD}^{+}$-dependent protein deacetylases that cleave off acetyl, as well as other acyl groups, from the $\varepsilon$-amino group of lysines in histones, but also in other substrate proteins. Seven sirtuin (SIRT1-7) isotypes have been identified in mammalian cells. Compared with normal mice, Sirt1-null mice are smaller, and have cranio-facial abnormalities ${ }^{(66,67)}$. Additionally, SIRT1 KO mice exhibit delays in long bone mineralization ${ }^{(68)}$ and possess an altered cartilage phenotype, characterized by low levels of type II collagen, aggrecan and glycosaminoglycan (GAG) content and a high level of MMP-13 ${ }^{(69)}$. Additional observations showed that, like heterozygous SIRT1 mice, SIRT1-null mice exhibit increased chondrocyte apoptosis and OA severity with age, as compared to equivalent WT mice ${ }^{(69,70)}$. SIRT1 also promotes chondrocyte survival under various stress conditions ${ }^{(70-74)}$, further supporting its role in maintaining cartilage homoeostasis. Furthermore, Sirtuin 6 (SIRT6) has been found highly expressed in the growth plate preferentially in proliferating and prehypertrophic chondrocytes. Homozygous SIRT6 null mice are smaller than their wild-type (WT) littermates at birth and exhibit defects in proliferation and hypertrophic chondrocyte differentiation, by interacting with the IHH signaling pathway ${ }^{(75)}$.

In contrast to deacetylation, various in vitro and in vivo studies demonstrate that histone acetylation favors cartilage differentiation. In particular, the HAT p300 potentiates SOX9- 
dependent transcription through histone hyperacetylation. Beside its HAT activity, p300 can also acetylate non histone proteins. It can act as a coactivator to cartilage homeoprotein-1 (CART1), a protein expressed selectively in chondrocyte lineage during embryonic development ${ }^{(76)}$, through acetylation of the conserved lysine residue adjacent to the homeodomain ${ }^{(77)}$. During chondrogenesis, SOX9 also specifically interacts with Tat interactive protein-60 (Tip60) to increase acetylation of SOX9 and subsequent enhancement of its transcriptional activity ${ }^{(78)}$.

\section{Histone methylation}

Besides acetylation, histones can undergo methylation. This post-tranlational modification is driven by histone methyltransferases (HMT) which add a methyl group (-CH3) to lysine or arginine residues at the $\mathrm{N}$-terminal tail of histones.

The methylation of histone lysine residues is associated with either transcription activation or repression depending on concerned amino acid. Indeed, lysine methylation is interpreted by both positive and negative transcription regulators. For instance, histone H3 lysine 4 trimethylation (H3K4me3) and $\mathrm{H} 3 \mathrm{~K} 36 \mathrm{me} 3$ are associated with gene expression, while H3K27me3 and H3K9me3 are associated with transcriptional repression.

Histone methylation is dynamically regulated during endochondral ossification by various histone methyltransferases and demethylases. For instance, H3K9 methyltransferases including PR domain zinc finger protein 2 (PRDM2), Suppressor of variegation 3-9, drosophila homolog of 1 and 2 (SUV39H1, SUV39H2) G9a, GLP (G9a-like protein) and ERG-associated protein with SET domain (ESET) are predominantly expressed in both prehypertrophic and hypertrophic chondrocytes during mouse growth plate development. These expression patterns overlap with the distributions of H3K9 HKM, especially H3K9me1 and $\mathrm{H} 3 \mathrm{~K} 9 \mathrm{me} 3$. In addition, $\mathrm{H} 3 \mathrm{~K} 9$ methyltransferases and $\mathrm{H} 3 \mathrm{~K} 9 \mathrm{me} 3$ are enriched within 
trabecular bone ${ }^{(79)}$. ESET, a H3K9-specific histone methyltransferase also called Set domain protein bifurcated 1 (SETDB1), is transiently upregulated in prehypertrophic chondrocytes in newborn mice. ESET controls hypertrophic differentiation of growth plate chondrocytes and formation of epiphyseal plates ${ }^{(80)}$, as well as the terminal differentiation of articular chondrocytes ${ }^{(81)}$. ESET conditional deletion in mesenchymal cells causes acceleration of chondrocyte hypertrophy during embryonic and prenatal development, resulting in a defect in long bone growth and trabecular bone formation. This effect is associated with a significant reduction of $\mathrm{IHH}$ protein in pre- and early hypertrophic chondrocytes. One of mechanism explaining this phenotype is that ESET physically interacts with both RUNX2 and HDAC4 to repress the expression of RUNX2 target genes by a H3K9 methylation-dependent mechanism ${ }^{(80)}$. Conversely, the transcription factor AT-rich interactive domain 5b (ARIB5b) facilitates chondrocyte differentiation and promotes expression of chondrogenic genes by recruiting the H3K9me2 demethylase PHD Finger Protein 2 (PHF2) to SOX9-regulated chondrogenic gene promoters ${ }^{(82)}$.

H3K27 methylation plays also a crucial role in the regulation of chondrocyte proliferation and hypertrophy. H3K27 methylation is regulated by the histone methyltransferase Enhancer of zeste homolog $2(\mathrm{EZH} 2)$. In contrast, H3K27 methylation is removed by the demethylases Jumonji domain containing-3 (JMJD3) and ubiquitously transcribed tetratricopeptide repeat gene on X chromosome (UTX), also called KDM6B and KDM6A, respectively. Loss of both EZH2 and its homolog EZH1 in cartilage induces severe growth retardation in mice, characterized by the alteration of chondrocyte proliferation due to an increase of cyclindependent kinase inhibitors $\mathrm{CDKN} 2 \mathrm{a} / \mathrm{b}$, and changes in chondrocyte hypertrophy due to the inhibition of insulin-like growth factor (IGF) signaling by IGF-binding proteins (IGFBP). Both increases of CDKN2a/b and IGFBP are linked to a decrease of H3K27me3 on their respective promoter ${ }^{(83)}$. Also, conditional inactivation of EZH2 prevents craniofacial bone 
and cartilage formation, due to massive derepression of HOX genes in neural crest cells that are usually devoid of HOX gene expression ${ }^{(84)}$.

Conversely, JMJD3-deficient mice exhibit markedly reduced proliferation and hypertrophy of chondrocytes and a severe delay of endochondral ossification. This histone demethylase is highly expressed in prehypertrophic and hypertrophic chondrocytes during endochondral bone formation. Genetic and biochemical analysis reveal that JMJD3 cooperates with RUNX2 to promote chondrocyte proliferation and hypertrophy. JMJD3 acts as a RUNX2 co-activator and this interaction not only induces H3K27me3-demethylation-dependent RUNX2 expression, but also recruits RUNX2 on the JMJD3 promoter ${ }^{(85)}$. JMJD3 expression increases during TGF- $\beta$ induced MSC chondrogenesis ${ }^{(86)}$. Moreover, incubation with the H3K27 demethylase inhibitor GSK-J4 during chondrogenesis inhibits MEC synthesis and chondrogenic gene expression by MSCs ${ }^{(86)}$.

The histone-lysine N-methyltransferase DOT1L likely also plays a role in chondrogenesis. This H3 lysine-79 specific methyltransferase is strongly expressed within mouse developing limbs during chondrogenesis. Furthermore knockdown studies in ATDC5 cells suggest that DOT1L is involved in chondrogenic differentiation, presumably through the regulation of canonical WNT-signaling ${ }^{(87)}$.

\section{miRNA}

Non coding RNA (ncRNA), particularly miRNA, are important epigenetic regulators of physiological and pathological processes.

MiRNA are evolutionarily conserved non-coding RNA measuring approximately 22 nucleotides that control translation and/or mRNA degradation ${ }^{(88)}$. Biogenesis of miRNA (figure 3) begins in the nucleus by their transcription as primary miRNA (pri-miRNA). Next, the pri-miRNA undergoes a first cleavage catalyzed by a complex formed by DROSHA and 
DiGeorge syndrome critical region 8 (DGCR8), to produce a miRNA precursor (pre-miRNA). This pre-miRNA is then exported to the cytoplasm by Exportine-5-RAS-related nuclear protein guanosine 5'-triphosphate (Exportine-5-RAN-GTP). The maturation continues with a second cleavage by the RNase III DICER, which produces a miRNA duplex. The miRNA guide strand is next loaded into miRNA-induced silencing complex (miRISC) containing DICER1 and Argonaute (AGO) proteins to mediate gene extinction ${ }^{(89)}$.

Interestingly, germlime deletion of DICER limits growth plate chondrocyte proliferation and accelerates differentiation into post-mitotic hypertrophic chondrocytes, leading to severe skeletal growth defects ${ }^{(90)}$. In addition, in vitro knockdown of DICER inhibits chondrogenic differentiation, showing that miRNA machinery is also crucial for chondrogenesis ${ }^{(91)}$. MiRNA microarray analysis highlight that miR-193b, miR-199a-3p/hsa-miR-199b-3p, miR455-3p, miR-381, miR-92a, miR-320c, and miR-136 miR-23b, miR-140, miR-181 and miR210 are upregulated during MSCs differentiation into chondrocytes, while miR-490-5p, miR4287, miR-BART8, and miR-US25-1 are downregulated ${ }^{(92,93)}$. The roles of the majority of these miRNA are still largely unknown, but several studies demonstrate the crucial role of miR-410. Mice deficient in miR-140 present an impairment of longitudinal bone growth and an acceleration of hypertrophic differentiation ${ }^{(94)}$. Among others, miR-140 targets p38 MAPK signaling pathway, which promotes activity and expression of mads box transcription enhancer factor 2, polypeptide C (MEF2C), a transcription factor that controls chondrocyte hypertrophy and bone development ${ }^{(61,94)}$. Furthermore, in vitro, miR-140 expression has been found to increase in parallel with SOX9 and COL2A1 during MSC chondrogenic differentiation in vitro ${ }^{(95)}$; thus, miR-140 may promote chondrogenesis by enhancing WNT signaling (91). Moreover, this miRNA consistently decreases during chondrocyte dedifferentiation and its expression is recovered during re-differentiation in a 3D culture with TGF- $\beta 1{ }^{(96)}$. miR-23b was also described as a miRNA promoting MSC chondrogenic 


\section{Long non-coding RNAs}

Long non-coding RNA (lncRNA) are a class of RNA transcripts longer than 200 nucleotides lacking open reading frames. They are important regulators of a variety of biological processes, including transcriptional regulation, mRNA processiong and stability, chromatin organization and scaffolding for multi-protein complexes ${ }^{(104)}$. Whereas a vast number of IncRNA are expressed in human cells, their physiological functions remain mostly unknown. Even fewer studies have investigated their role in endochondral ossification and/or cartilage development and maintenance ${ }^{(105)}$ : however, one of the best-studied lncRNA is HOTAIR. Among its multiple roles, it is now clear that this lncRNA regulates skeletal element development. Indeed, mice lacking HOTAIR exhibit homeotic transformation of the spine and malformation of metacarpal-carpal bones ${ }^{(106)}$. Mechanistically, HOTAIR recruits PRC2 to the HOXD cluster, where it mediates H3K27 methylation to repress the expression of several 5' HOXD genes ${ }^{(107)}$, namely HOXD11 and HOXD13 ${ }^{(106)}$.

The IncRNA HOTTIP functions as an enhancer to regulate the expression of 5' HOXA genes and control the growth and elongation of zeugopod and autopod skeletal elements ${ }^{(108)}$. At 
molecular level, HOTTIP modulates gene expression by chromosomal looping, placing the recruited Trithorax/WDR5/MLL protein complexes proximal to 5' HOXA genes to facilitate H3K4me3 and gene expression ${ }^{(108,109)}$. Additionally, HOTTIP function is associated with endochondral ossification ${ }^{(110)}$. Also, lncRNA-HIT was identified within the HOXA locus (111). This lncRNA is expressed in mice embryo limb mesenchyme just before cartilaginous differentiation ${ }^{(105)}$. IncRNA-HIT associates with chondrogenic genes and promotes their expression by recruiting p100 and the histone acetyltransferase CREB-binding protein (CBP) (105)

The lncRNA DANCR may also promote chondrogenic differentiation of synovium-derived MSCs (SMSC) in concert with SOX4 ${ }^{(112)}$, by interaction with SMAD3, and STAT3 mRNA to regulate their stability ${ }^{(113)}$. DANCR favors also SMSC proliferation through MYC regulation ${ }^{(113)}$. Other Sox transcription factors interact also with lncRNA. For instance, ROCR, which is induced during chondrogenic differentiation, plays an important role in the induction of SOX9 and cartilage gene expression ${ }^{(114)}$. Similarly, UCA1 plays an important role in the skeletal development ${ }^{(115)}$. UCA1 is expressed in normal human chondrocytes and favors chondrocyte differentiation of these cells, but UCA1 is not detected in human bone marrow mesenchymal stem cells (hBMSCs).

H19 is also a new player in musculoskeletal system. H19 could promote osteogenic differentiation by suppressing the TGF- $\beta / \mathrm{pSmad} 3 /$ histone deacetylase $4 / 5$ (HDAC4/5) signaling pathway, and enhancing the expression of osteogenic marker genes such as RUNX2 and osteocalcine $(\mathrm{OCN})$, and by serving as a competing endogenous RNA for both miR-141 and miR-22, which are the negative regulators of WNT/ $\beta$-catenin signaling. H19 could also promote chondrogenic differentiation, in particular H19 may regulate the expression of collagen type 2 through miR-675 ${ }^{(116)}$. 


\section{Conclusion and perspectives}

Chondrogenesis during both MSC chondrogenic differentiation and endochondral ossification is intrinsically controlled by epigenetic mechanisms, including DNA methylation, histone post-translational modification and non-coding RNA. All these regulatory processes are strongly interconnected together.

Investigations of their involvement during endochondral ossification as well as cartilage differentiation and stability could be useful in cartilage tissue-engineering applications. For instance, inhibition of DNA methylation or effective miRNA-based treatment modalities that should have minimal or no off-target side effects, could provide promising approaches to maintain the chondrocyte phenotype. A better understanding of epigenetic regulation during chondrogenesis and chondrocyte terminal differentiation and hypertrophy may open new strategies to decelerate chondrocyte dedifferentiation and hypertrophy observed during autologous chondrocyte implantation, or to promote chondrogenesis of stem cells. Consequently, more information regarding how epigenetic regulations established and maintains the chondrocyte phenotype is required and new "epidrugs" need to be developed improve the outcome of cartilage cell therapy.

Competing interests: Authors declare no competing interests.

Fundings: Agence Nationale de la Recherche [ANR-15-CE14-0002-01], Région Normandie, European Union [FEDER/FSE 2014-2020 - 16E00779/16P03685] and the Société Française de Rhumatologie (SFR)

\section{References}


1. Perry AS, Watson RWG, Lawler M, Hollywood D. The epigenome as a therapeutic target in prostate cancer. Nat. Rev. Urol. 2010 Dec;7(12):668-80.

2. Kato M, Yasuda S, Atsumi T. The role of genetics and epigenetics in rheumatic diseases: are they really a target to be aimed at? Rheumatol. Int. 2018 Aug;38(8):1333-8.

3. Malemud CJ. MicroRNAs and Osteoarthritis. Cells. 2018 Aug 1;7(8).

4. Del Real A, Riancho-Zarrabeitia L, López-Delgado L, Riancho JA. Epigenetics of Skeletal Diseases. Curr. Osteoporos. Rep. 2018 Jun;16(3):246-55.

5. Peffers MJ, Balaskas P, Smagul A. Osteoarthritis year in review 2017: genetics and epigenetics. Osteoarthritis Cartilage. 2018 Mar;26(3):304-11.

6. Long F, Ornitz DM. Development of the Endochondral Skeleton. Cold Spring Harb. Perspect. Biol. [Internet]. 2013 Jan;5(1). Available from: https://www.ncbi.nlm.nih.gov/pmc/articles/PMC3579395/

7. Wang W, Rigueur D, Lyons KM. TGF $\beta$ Signaling in Cartilage Development and Maintenance. Birth Defects Res. Part C Embryo Today Rev. 2014 Mar;102(1):37-51.

8. Hata K, Takahata Y, Murakami T, Nishimura R. Transcriptional Network Controlling Endochondral Ossification. J. Bone Metab. 2017 May;24(2):75-82.

9. Inada M, Wang Y, Byrne MH, Rahman MU, Miyaura C, López-Otín C, Krane SM. Critical roles for collagenase-3 (Mmp13) in development of growth plate cartilage and in endochondral ossification. Proc. Natl. Acad. Sci. U. S. A. 2004 Dec 7;101(49):17192-7.

10. Shapiro IM, Adams CS, Freeman T, Srinivas V. Fate of the hypertrophic chondrocyte: microenvironmental perspectives on apoptosis and survival in the epiphyseal growth plate. Birth Defects Res. Part C Embryo Today Rev. 2005 Dec;75(4):330-9.

11. Staines KA, Pollard AS, McGonnell IM, Farquharson C, Pitsillides AA. Cartilage to bone transitions in health and disease. J. Endocrinol. 2013 Oct;219(1):R1-12.

12. Pacifici M, Koyama E, Shibukawa Y, Wu C, Tamamura Y, Enomoto-Iwamoto M, Iwamoto M. Cellular and Molecular Mechanisms of Synovial Joint and Articular Cartilage Formation. Ann. N. Y. Acad. Sci. 2006 Apr;1068:74-86.

13. Ito MM, Kida MY. Morphological and biochemical re-evaluation of the process of cavitation in the rat knee joint: cellular and cell strata alterations in the interzone. J. Anat. $2000 \mathrm{Nov} ; 197 \mathrm{Pt}$ 4:659-79.

14. Ng L, Tam PP, Cheah KS. Preferential expression of alternatively spliced mRNAs encoding type II procollagen with a cysteine-rich amino-propeptide in differentiating cartilage and nonchondrogenic tissues during early mouse development. Dev. Biol. 1993 Oct;159(2):40317.

15. Pitsillides AA, Ashhurst DE. A critical evaluation of specific aspects of joint development. Dev. Dyn. Off. Publ. Am. Assoc. Anat. 2008 Sep;237(9):2284-94.

16. Bird A. DNA methylation patterns and epigenetic memory. Genes Dev. 2002 Jan 1;16(1):6-21. 
17. Hattori N, Nishino K, Ko Y-G, Hattori N, Ohgane J, Tanaka S, Shiota K. Epigenetic control of mouse Oct-4 gene expression in embryonic stem cells and trophoblast stem cells. J. Biol. Chem. 2004 Apr 23;279(17):17063-9.

18. Hattori N, Imao Y, Nishino K, Hattori N, Ohgane J, Yagi S, Tanaka S, Shiota K. Epigenetic regulation of Nanog gene in embryonic stem and trophoblast stem cells. Genes Cells. 2007 Mar 1;12(3):387-96.

19. Takahashi K, Yamanaka S. Induction of Pluripotent Stem Cells from Mouse Embryonic and Adult Fibroblast Cultures by Defined Factors. Cell. 2006 Aug 25;126(4):663-76.

20. Amir RE, Van den Veyver IB, Wan M, Tran CQ, Francke U, Zoghbi HY. Rett syndrome is caused by mutations in X-linked MECP2, encoding methyl-CpG-binding protein 2. Nat. Genet. 1999 Oct;23(2):185-8.

21. Egger G, Liang GN, Aparicio A, Jones PA. Epigenetics in human disease and prospects for epigenetic therapy. Nature. 2004 May 27;429(6990):457-63.

22. Ehrlich M. The ICF syndrome, a DNA methyltransferase 3B deficiency and immunodeficiency disease. Clin. Immunol. 2003 Oct;109(1):17-28.

23. Mohn F, Weber M, Rebhan M, Roloff TC, Richter J, Stadler MB, Bibel M, Schübeler D. Lineagespecific polycomb targets and de novo DNA methylation define restriction and potential of neuronal progenitors. Mol. Cell. 2008 Jun 20;30(6):755-66.

24. Fernández MP, Young MF, Sobel ME. Methylation of type II and type I collagen genes in differentiated and dedifferentiated chondrocytes. J. Biol. Chem. 1985 Feb 25;260(4):2374-8.

25. Ezura Y, Sekiya I, Koga H, Muneta T, Noda M. Methylation status of CpG islands in the promoter regions of signature genes during chondrogenesis of human synovium-derived mesenchymal stem cells. Arthritis Rheum. 2009 May;60(5):1416-26.

26. Boquest AC, Noer A, Sorensen AL, Vekterud K, Collas P. CpG methylation profiles of endothelial cell-specific gene promoter regions in adipose tissue stem cells suggest limited differentiation potential toward the endothelial cell lineage. Stem Cells. 2007;25(4):852-61.

27. Kang M-I, Kim H-S, Jung Y-C, Kim Y-H, Hong S-J, Kim M-K, Baek K-H, Kim C-C, Rhyu M-G. Transitional CpG methylation between promoters and retroelements of tissue-specific genes during human mesenchymal cell differentiation. J. Cell. Biochem. 2007 Sep 1;102(1):224-39.

28. Kawai J, Hirose K, Fushiki S, Hirotsune S, Ozawa N, Hara A, Hayashizaki Y, Watanabe S. Comparison of Dna Methylation Patterns Among Mouse-Cell Lines by Restriction Landmark Genomic Scanning. Mol. Cell. Biol. 1994 Nov;14(11):7421-7.

29. Noer A, Sorensen AL, Boquest AC, Collas P. Stable CpG hypomethylation of adipogenic promoters in freshly isolated, cultured, and differentiated mesenchymal stem cells from adipose tissue. Mol. Biol. Cell. 2006 Aug;17(8):3543-56.

30. Zimmermann P, Boeuf S, Dickhut A, Boehmer S, Olek S, Richter W. Correlation of COL10A1 induction during chondrogenesis of mesenchymal stem cells with demethylation of two CpG sites in the COL10A1 promoter. Arthritis Rheum. 2008 Sep;58(9):2743-53. 
31. Shen J, Wang C, Li D, Xu T, Myers J, Ashton JM, Wang T, Zuscik MJ, McAlinden A, O'Keefe RJ. DNA methyltransferase $3 \mathrm{~b}$ regulates articular cartilage homeostasis by altering metabolism. JCl Insight. 2017 Jun 15;2(12).

32. Wang C, Abu-Amer Y, O'Keefe RJ, Shen J. Loss of Dnmt3b in Chondrocytes Leads to Delayed Endochondral Ossification and Fracture Repair. J. Bone Miner. Res. Off. J. Am. Soc. Bone Miner. Res. 2018 Feb;33(2):283-97.

33. Xu T, Wang C, Shen J, Tong P, O'Keefe R. Ablation of Dnmt3b in chondrocytes suppresses cell maturation during embryonic development. J. Cell. Biochem. 2018 Jul 1;119(7):5852-63.

34. El-Serafi AT, Oreffo ROC, Roach HI. Epigenetic modifiers influence lineage commitment of human bone marrow stromal cells: Differential effects of 5-aza-deoxycytidine and trichostatin A. Differ. Res. Biol. Divers. 2011 Jan;81(1):35-41.

35. Zhou G-S, Zhang X-L, Wu J-P, Zhang R-P, Xiang L-X, Dai L-C, Shao J-Z. 5-Azacytidine facilitates osteogenic gene expression and differentiation of mesenchymal stem cells by alteration in DNA methylation. Cytotechnology. 2009 Jul;60(1-3):11-22.

36. Zuscik MJ, Baden JF, Wu Q, Sheu TJ, Schwarz EM, Drissi H, O'Keefe RJ, Puzas JE, Rosier RN. 5azacytidine alters TGF-beta and BMP signaling and induces maturation in articular chondrocytes. J. Cell. Biochem. 2004 May 15;92(2):316-31.

37. Ho M-L, Chang J-K, Wu S-C, Chung Y-H, Chen C-H, Hung S-H, Wang G-J. A novel terminal differentiation model of human articular chondrocytes in three-dimensional cultures mimicking chondrocytic changes in osteoarthritis. Cell Biol. Int. 2006 Mar;30(3):288-94.

38. Haq SH. 5-Aza-2'-deoxycytidine acts as a modulator of chondrocyte hypertrophy and maturation in chick caudal region chondrocytes in culture. Anat. Cell Biol. 2016 Jun;49(2):10715.

39. Ito S, D'Alessio AC, Taranova OV, Hong K, Sowers LC, Zhang Y. Role of Tet proteins in $5 \mathrm{mC}$ to $5 \mathrm{hmC}$ conversion, ES cell self-renewal, and ICM specification. Nature. 2010 Aug 26;466(7310):1129-33.

40. Ito S, Shen L, Dai Q, Wu SC, Collins LB, Swenberg JA, He C, Zhang Y. Tet proteins can convert 5methylcytosine to 5-formylcytosine and 5-carboxylcytosine. Science. 2011 Sep 2;333(6047):1300-3.

41. Tahiliani M, Koh KP, Shen Y, Pastor WA, Bandukwala H, Brudno Y, Agarwal S, Iyer LM, Liu DR, Aravind L, Rao A. Conversion of 5-Methylcytosine to 5-Hydroxymethylcytosine in Mammalian DNA by MLL Partner TET1. Science. 2009 May 15;324(5929):930-5.

42. Taylor SEB, Li YH, Smeriglio P, Rath M, Wong WH, Bhutani N. Stable 5-Hydroxymethylcytosine (5hmC) Acquisition Marks Gene Activation During Chondrogenic Differentiation. J. Bone Miner. Res. Off. J. Am. Soc. Bone Miner. Res. 2016 Mar;31(3):524-34.

43. Bradley EW, McGee-Lawrence ME, Westendorf JJ. Hdac-Mediated Control of Endochondral and Intramembranous Ossification. Crit. Rev. Eukaryot. Gene Expr. 2011;21(2):101-13.

44. Jeon E-J, Lee K-Y, Choi N-S, Lee M-H, Kim H-N, Jin Y-H, Ryoo H-M, Choi J-Y, Yoshida M, Nishino $\mathrm{N}$, Oh B-C, Lee K-S, Lee $\mathrm{YH}$, Bae S-C. Bone morphogenetic protein-2 stimulates Runx2 acetylation. J. Biol. Chem. 2006 Jun 16;281(24):16502-11. 
45. Chang S, McKinsey TA, Zhang CL, Richardson JA, Hill JA, Olson EN. Histone deacetylases 5 and 9 govern responsiveness of the heart to a subset of stress signals and play redundant roles in heart development. Mol. Cell. Biol. 2004 Oct;24(19):8467-76.

46. Trivedi CM, Luo Y, Yin Z, Zhang M, Zhu W, Wang T, Floss T, Goettlicher M, Noppinger PR, Wurst W, Ferrari VA, Abrams CS, Gruber PJ, Epstein JA. Hdac2 regulates the cardiac hypertrophic response by modulating Gsk3 beta activity. Nat. Med. 2007 Mar;13(3):324-31.

47. Vega RB, Matsuda K, Oh J, Barbosa AC, Yang X, Meadows E, McAnally J, Pomajzl C, Shelton JM, Richardson JA, Karsenty G, Olson EN. Histone Deacetylase 4 Controls Chondrocyte Hypertrophy during Skeletogenesis. Cell. 2004 Nov 12;119(4):555-66.

48. Murtaugh LC, Zeng L, Chyung JH, Lassar AB. The chick transcriptional repressor Nkx3.2 acts downstream of Shh to promote BMP-dependent axial chondrogenesis. Dev. Cell. 2001 Sep;1(3):411-22.

49. Zeng L, Kempf H, Murtaugh LC, Sato ME, Lassar AB. Shh establishes an Nkx3.2/Sox9 autoregulatory loop that is maintained by BMP signals to induce somitic chondrogenesis. Genes Dev. 2002 Aug 1;16(15):1990-2005.

50. Kim D-W, Lassar AB. Smad-Dependent Recruitment of a Histone Deacetylase/Sin3A Complex Modulates the Bone Morphogenetic Protein-Dependent Transcriptional Repressor Activity of Nkx3.2. Mol. Cell. Biol. 2003 Dec;23(23):8704-17.

51. Hong S, Derfoul A, Pereira-Mouries L, Hall DJ. A novel domain in histone deacetylase 1 and 2 mediates repression of cartilage-specific genes in human chondrocytes. FASEB J. 2009 Oct;23(10):3539-52.

52. Lee HW, Suh JH, Kim AY, Lee YS, Park SY, Kim JB. Histone deacetylase 1-mediated histone modification regulates osteoblast differentiation. Mol. Endocrinol. Baltim. Md. 2006 Oct;20(10):2432-43.

53. Razidlo DF, Whitney TJ, Casper ME, McGee-Lawrence ME, Stensgard BA, Li X, Secreto FJ, Knutson SK, Hiebert SW, Westendorf JJ. Histone Deacetylase 3 Depletion in Osteo/Chondroprogenitor Cells Decreases Bone Density and Increases Marrow Fat. PLoS ONE [Internet]. $2010 \mathrm{Jul}$ 9;5(7). Available from:

https://www.ncbi.nlm.nih.gov/pmc/articles/PMC2901996/

54. Bradley EW, Carpio LR, Westendorf JJ. Histone deacetylase 3 suppression increases PH domain and leucine-rich repeat phosphatase (Phlpp)1 expression in chondrocytes to suppress Akt signaling and matrix secretion. J. Biol. Chem. 2013 Apr 5;288(14):9572-82.

55. Carpio LR, Westendorf JJ. Histone Deacetylases in Cartilage Homeostasis and Osteoarthritis. Curr. Rheumatol. Rep. 2016 Aug;18(8):52.

56. Carpio LR, Bradley EW, McGee-Lawrence ME, Weivoda MM, Poston DD, Dudakovic A, Xu M, Tchkonia T, Kirkland JL, van Wijnen AJ, Oursler MJ, Westendorf JJ. Histone deacetylase 3 supports endochondral bone formation by controlling cytokine signaling and matrix remodeling. Sci. Signal. 2016 09;9(440):ra79.

57. Correa D, Hesse E, Seriwatanachai D, Kiviranta R, Saito H, Yamana K, Neff L, Atfi A, Coillard L, Sitara D, Maeda Y, Warming S, Jenkins NA, Copeland NG, Horne WC, Lanske B, Baron R. 
Zfp521 Is a Target Gene and Key Effector of Parathyroid Hormone-Related Peptide Signaling in Growth Plate Chondrocytes. Dev. Cell. 2010 Oct 19;19(4):533-46.

58. Kozhemyakina E, Cohen T, Yao T-P, Lassar AB. Parathyroid hormone-related peptide represses chondrocyte hypertrophy through a protein phosphatase 2A/histone deacetylase 4/MEF2 pathway. Mol. Cell. Biol. 2009 Nov;29(21):5751-62.

59. Jensen ED, Schroeder TM, Bailey J, Gopalakrishnan R, Westendorf JJ. Histone Deacetylase 7 Associates With Runx2 and Represses Its Activity During Osteoblast Maturation in a Deacetylation-Independent Manner. J. Bone Miner. Res. 2008 Mar;23(3):361-72.

60. Jensen ED, Gopalakrishnan R, Westendorf JJ. Bone morphogenic protein 2 activates protein kinase $D$ to regulate histone deacetylase 7 localization and repression of Runx2. J. Biol. Chem. 2009 Jan 23;284(4):2225-34.

61. Zhou J, Li P, Chen Q, Wei X, Zhao T, Wang Z, Wei L. Mitogen-activated protein kinase p38 induces HDAC4 degradation in hypertrophic chondrocytes. Biochim. Biophys. Acta. 2015 Feb;1853(2):370-6.

62. Kang JS, Alliston T, Delston R, Derynck R. Repression of Runx2 function by TGF-beta through recruitment of class II histone deacetylases by Smad3. EMBO J. 2005 Jul 20;24(14):2543-55.

63. Westendorf JJ, Zaidi SK, Cascino JE, Kahler R, van Wijnen AJ, Lian JB, Yoshida M, Stein GS, Li X. Runx2 (Cbfa1, AML-3) interacts with histone deacetylase 6 and represses the p21(CIP1/WAF1) promoter. Mol. Cell. Biol. 2002 Nov;22(22):7982-92.

64. Zhang Y, Kwon S, Yamaguchi T, Cubizolles F, Rousseaux S, Kneissel M, Cao C, Li N, Cheng H-L, Chua K, Lombard D, Mizeracki A, Matthias G, Alt FW, Khochbin S, Matthias P. Mice lacking histone deacetylase 6 have hyperacetylated tubulin but are viable and develop normally. Mol. Cell. Biol. 2008 Mar;28(5):1688-701.

65. Bradley EW, Carpio LR, Olson EN, Westendorf JJ. Histone Deacetylase 7 (Hdac7) Suppresses Chondrocyte Proliferation and $\beta$-Catenin Activity during Endochondral Ossification. J. Biol. Chem. 2015 Jan 2;290(1):118-26.

66. McBurney MW, Yang X, Jardine K, Bieman M, Th'ng J, Lemieux M. The absence of SIR2alpha protein has no effect on global gene silencing in mouse embryonic stem cells. Mol. Cancer Res. MCR. 2003 Mar;1(5):402-9.

67. McBurney MW, Yang X, Jardine K, Hixon M, Boekelheide K, Webb JR, Lansdorp PM, Lemieux $M$. The mammalian SIR2alpha protein has a role in embryogenesis and gametogenesis. Mol. Cell. Biol. 2003 Jan;23(1):38-54.

68. Lemieux ME, Yang X, Jardine K, He X, Jacobsen KX, Staines WA, Harper ME, McBurney MW. The Sirt1 deacetylase modulates the insulin-like growth factor signaling pathway in mammals. Mech. Ageing Dev. 2005 Oct;126(10):1097-105.

69. Gabay O, Zaal KJ, Sanchez C, Dvir-Ginzberg M, Gagarina V, Song Y, He XH, McBurney MW. Sirt1-deficient mice exhibit an altered cartilage phenotype. Jt. Bone Spine Rev. Rhum. 2013 Dec;80(6):613-20. 
70. Gabay O, Oppenhiemer H, Meir H, Zaal K, Sanchez C, Dvir-Ginzberg M. Increased apoptotic chondrocytes in articular cartilage from adult heterozygous SirT1 mice. Ann. Rheum. Dis. 2012 Apr;71(4):613-6.

71. Dvir-Ginzberg M, Gagarina V, Lee EJ, Booth R, Gabay O, Hall DJ. Tumor necrosis factor $\alpha$ mediated cleavage and inactivation of SirT1 in human osteoarthritic chondrocytes. Arthritis Rheum. 2011 Aug;63(8):2363-73.

72. Gagarina V, Gabay O, Dvir-Ginzberg M, Lee EJ, Brady JK, Quon MJ, Hall DJ. SirT1 enhances survival of human osteoarthritic chondrocytes by repressing protein tyrosine phosphatase $1 \mathrm{~B}$ and activating the insulin-like growth factor receptor pathway. Arthritis Rheum. 2010 May;62(5):1383-92.

73. Oppenheimer H, Gabay O, Meir H, Haze A, Kandel L, Liebergall M, Gagarina V, Lee EJ, DvirGinzberg M. 75-kd sirtuin 1 blocks tumor necrosis factor $\alpha$-mediated apoptosis in human osteoarthritic chondrocytes. Arthritis Rheum. 2012 Mar;64(3):718-28.

74. Takayama K, Ishida K, Matsushita T, Fujita N, Hayashi S, Sasaki K, Tei K, Kubo S, Matsumoto T, Fujioka H, Kurosaka M, Kuroda R. SIRT1 regulation of apoptosis of human chondrocytes. Arthritis Rheum. 2009 Sep;60(9):2731-40.

75. Piao J, Tsuji K, Ochi H, Iwata M, Koga D, Okawa A, Morita S, Takeda S, Asou Y. Sirt6 regulates postnatal growth plate differentiation and proliferation via Ihh signaling. Sci. Rep. 2013 Oct 23;3:3022.

76. lioka T, Furukawa K, Yamaguchi A, Shindo H, Yamashita S, Tsukazaki T. P300/CBP acts as a coactivator to cartilage homeoprotein-1 (Cart1), paired-like homeoprotein, through acetylation of the conserved lysine residue adjacent to the homeodomain. J. Bone Miner. Res. Off. J. Am. Soc. Bone Miner. Res. 2003 Aug;18(8):1419-29.

77. Furumatsu T, Tsuda M, Yoshida K, Taniguchi N, Ito T, Hashimoto M, Ito T, Asahara H. Sox9 and p300 cooperatively regulate chromatin-mediated transcription. J. Biol. Chem. 2005 Oct 21;280(42):35203-8.

78. Hattori T, Coustry F, Stephens S, Eberspaecher H, Takigawa M, Yasuda H, de Crombrugghe B. Transcriptional regulation of chondrogenesis by coactivator Tip60 via chromatin association with Sox9 and Sox5. Nucleic Acids Res. 2008 May;36(9):3011-24.

79. Ideno H, Shimada A, Imaizumi K, Kimura H, Abe M, Nakashima K, Nifuji A. Predominant expression of $\mathrm{H} 3 \mathrm{~K} 9$ methyltransferases in prehypertrophic and hypertrophic chondrocytes during mouse growth plate cartilage development. Gene Expr. Patterns. 2013 Mar;13(34):84-90.

80. Yang L, Lawson KA, Teteak CJ, Zou J, Hacquebord J, Patterson D, Ghatan AC, Mei Q, ZielinskaKwiatkowska A, Bain SD, Fernandes RJ, Chansky HA. ESET histone methyltransferase is essential to hypertrophic differentiation of growth plate chondrocytes and formation of epiphyseal plates. Dev. Biol. 2013 Aug 1;380(1):99-110.

81. Lawson KA, Teteak CJ, Zou J, Hacquebord J, Ghatan A, Zielinska-Kwiatkowska A, Fernandes RJ, Chansky HA, Yang L. Mesenchyme-specific knockout of ESET histone methyltransferase causes ectopic hypertrophy and terminal differentiation of articular chondrocytes. J. Biol. Chem. 2013 Nov 8;288(45):32119-25. 
82. Hata K, Takashima R, Amano K, Ono K, Nakanishi M, Yoshida M, Wakabayashi M, Matsuda A, Maeda Y, Suzuki Y, Sugano S, Whitson RH, Nishimura R, Yoneda T. Arid5b facilitates chondrogenesis by recruiting the histone demethylase Phf2 to Sox9-regulated genes. Nat. Commun. 2013;4:2850.

83. Lui JC, Garrison P, Nguyen Q, Ad M, Keembiyehetty C, Chen W, Jee YH, Landman E, Nilsson O, Barnes KM, Baron J. EZH1 and EZH2 promote skeletal growth by repressing inhibitors of chondrocyte proliferation and hypertrophy. Nat. Commun. 2016 Nov 29;7:13685.

84. Schwarz D, Varum S, Zemke M, Schöler A, Baggiolini A, Draganova K, Koseki H, Schübeler D, Sommer L. Ezh2 is required for neural crest-derived cartilage and bone formation. Dev. Camb. Engl. 2014 Feb;141(4):867-77.

85. Zhang F, Xu L, Xu L, Xu Q, Li D, Yang Y, Karsenty G, Chen CD. JMJD3 promotes chondrocyte proliferation and hypertrophy during endochondral bone formation in mice. J. Mol. Cell Biol. $2015 \mathrm{Feb} ; 7(1): 23-34$.

86. Yapp C, Carr AJ, Price A, Oppermann U, Snelling SJB. H3K27me3 demethylases regulate in vitro chondrogenesis and chondrocyte activity in osteoarthritis. Arthritis Res. Ther. [Internet]. 2016 [cited 2016 Aug 31];18. Available from: http://www.ncbi.nlm.nih.gov/pmc/articles/PMC4936015/

87. Castaño Betancourt MC, Cailotto F, Kerkhof HJ, Cornelis FMF, Doherty SA, Hart DJ, Hofman A, Luyten FP, Maciewicz RA, Mangino M, Metrustry S, Muir K, Peters MJ, Rivadeneira F, Wheeler M, Zhang W, Arden N, Spector TD, Uitterlinden AG, Doherty M, Lories RJU, Valdes AM, van Meurs JBJ. Genome-wide association and functional studies identify the DOT1L gene to be involved in cartilage thickness and hip osteoarthritis. Proc. Natl. Acad. Sci. U. S. A. 2012 May 22;109(21):8218-23.

88. Ha M, Kim VN. Regulation of microRNA biogenesis. Nat. Rev. Mol. Cell Biol. 2014 Aug;15(8):509-24.

89. Ding XC, Weiler J, Großhans H. Regulating the regulators: mechanisms controlling the maturation of microRNAs. Trends Biotechnol. 2009 Jan 1;27(1):27-36.

90. Kobayashi T, Lu J, Cobb BS, Rodda SJ, McMahon AP, Schipani E, Merkenschlager M, Kronenberg HM. Dicer-dependent pathways regulate chondrocyte proliferation and differentiation. Proc. Natl. Acad. Sci. U. S. A. 2008 Feb 12;105(6):1949-54.

91. Barter MJ, Tselepi M, Gómez R, Woods S, Hui W, Smith GR, Shanley DP, Clark IM, Young DA. Genome-Wide MicroRNA and Gene Analysis of Mesenchymal Stem Cell Chondrogenesis Identifies an Essential Role and Multiple Targets for miR-140-5p. STEM CELLS. $2015 \mathrm{Nov}$ 1;33(11):3266-80.

92. Zhang Z, Kang Y, Zhang Z, Zhang H, Duan X, Liu J, Li X, Liao W. Expression of microRNAs during chondrogenesis of human adipose-derived stem cells. Osteoarthr. Cartil. OARS Osteoarthr. Res. Soc. 2012 Dec;20(12):1638-46.

93. Gabler J, Ruetze M, Kynast KL, Grossner T, Diederichs S, Richter W. Stage-Specific miRs in Chondrocyte Maturation: Differentiation-Dependent and Hypertrophy-Related miR Clusters and the miR-181 Family. Tissue Eng. Part A. 2015 Dec;21(23-24):2840-51. 
94. Papaioannou G, Mirzamohammadi F, Lisse TS, Nishimori S, Wein MN, Kobayashi T. MicroRNA140 Provides Robustness to the Regulation of Hypertrophic Chondrocyte Differentiation by the PTHrP-HDAC4 Pathway. J. Bone Miner. Res. Off. J. Am. Soc. Bone Miner. Res. 2015 Jun;30(6):1044-52.

95. Miyaki S, Nakasa T, Otsuki S, Grogan SP, Higashiyama R, Inoue A, Kato Y, Sato T, Lotz MK, Asahara $\mathrm{H}$. MicroRNA-140 is expressed in differentiated human articular chondrocytes and modulates interleukin-1 responses. Arthritis Rheum. 2009 Sep;60(9):2723-30.

96. Hong E, Reddi AH. Dedifferentiation and redifferentiation of articular chondrocytes from surface and middle zones: changes in microRNAs-221/-222, -140, and -143/145 expression. Tissue Eng. Part A. 2013 Apr;19(7-8):1015-22.

97. Ham O, Song B-W, Lee S-Y, Choi E, Cha M-J, Lee CY, Park J-H, Kim I-K, Chang W, Lim S, Lee CH, Kim S, Jang Y, Hwang K-C. The role of microRNA-23b in the differentiation of MSC into chondrocyte by targeting protein kinase A signaling. Biomaterials. 2012 Jun;33(18):4500-7.

98. Guérit D, Philipot D, Chuchana P, Toupet K, Brondello J-M, Mathieu M, Jorgensen C, Noël D. Sox9-regulated miRNA-574-3p inhibits chondrogenic differentiation of mesenchymal stem cells. PloS One. 2013;8(4):e62582.

99. Lee S, Yoon DS, Paik S, Lee K-M, Jang Y, Lee JW. microRNA-495 inhibits chondrogenic differentiation in human mesenchymal stem cells by targeting Sox9. Stem Cells Dev. 2014 Aug 1;23(15):1798-808.

100. Xu J, Kang Y, Liao W, Yu L. MiR-194 Regulates Chondrogenic Differentiation of Human Adipose-Derived Stem Cells by Targeting Sox5. PLOS ONE. 2012 Mar 1;7(3):e31861.

101. Cheung KSC, Sposito N, Stumpf PS, Wilson DI, Sanchez-Elsner T, Oreffo ROC. MicroRNA-146a Regulates Human Foetal Femur Derived Skeletal Stem Cell Differentiation by Down-Regulating SMAD2 and SMAD3. PLoS ONE [Internet]. 2014 Jun 3;9(6). Available from: https://www.ncbi.nlm.nih.gov/pmc/articles/PMC4043645/

102. Lolli A, Lambertini E, Penolazzi L, Angelozzi M, Morganti C, Franceschetti T, Pelucchi S, Gambari R, Piva R. Pro-chondrogenic effect of miR-221 and slug depletion in human MSCs. Stem Cell Rev. 2014 Dec;10(6):841-55.

103. Lolli A, Narcisi R, Lambertini E, Penolazzi L, Angelozzi M, Kops N, Gasparini S, van Osch GJVM, Piva R. Silencing of anti-chondrogenic microRNA-221 in human mesenchymal stem cells promotes cartilage repair in vivo. Stem Cells Dayt. Ohio. 2016 Mar 1;

104. Geisler S, Coller J. RNA in unexpected places: long non-coding RNA functions in diverse cellular contexts. Nat. Rev. Mol. Cell Biol. 2013 Nov;14(11):699-712.

105. Carlson HL, Quinn JJ, Yang YW, Thornburg CK, Chang HY, Stadler HS. LncRNA-HIT Functions as an Epigenetic Regulator of Chondrogenesis through Its Recruitment of p100/CBP Complexes. PLoS Genet. 2015 Dec;11(12):e1005680.

106. Li L, Liu B, Wapinski OL, Tsai M-C, Qu K, Zhang J, Carlson JC, Lin M, Fang F, Gupta RA, Helms JA, Chang HY. Targeted disruption of Hotair leads to homeotic transformation and gene derepression. Cell Rep. 2013 Oct 17;5(1):3-12. 
107. Rinn JL, Kertesz $M$, Wang JK, Squazzo SL, Xu X, Brugmann SA, Goodnough $H$, Helms JA, Farnham PJ, Segal E, Chang HY. Functional Demarcation of Active and Silent Chromatin Domains in Human HOX Loci by Non-Coding RNAs. Cell. 2007 Jun 29;129(7):1311-23.

108. Wang KC, Yang YW, Liu B, Sanyal A, Corces-Zimmerman R, Chen Y, Lajoie BR, Protacio A, Flynn RA, Gupta RA, Wysocka J, Lei M, Dekker J, Helms JA, Chang HY. Long noncoding RNA programs active chromatin domain to coordinate homeotic gene activation. Nature. $2011 \mathrm{Apr}$ 7;472(7341):120-4.

109. Schuettengruber B, Chourrout D, Vervoort M, Leblanc B, Cavalli G. Genome regulation by polycomb and trithorax proteins. Cell. 2007 Feb 23;128(4):735-45.

110. Kim D, Song J, Han J, Kim Y, Chun C-H, Jin E-J. Two non-coding RNAs, MicroRNA-101 and HOTTIP contribute cartilage integrity by epigenetic and homeotic regulation of integrin- $\alpha 1$. Cell. Signal. 2013 Dec;25(12):2878-87.

111. Richards EJ, Zhang G, Li Z-P, Permuth-Wey J, Challa S, Li Y, Kong W, Dan S, Bui MM, Coppola D, Mao W-M, Sellers TA, Cheng JQ. Long Non-coding RNAs (LncRNA) Regulated by Transforming Growth Factor (TGF) ß. J. Biol. Chem. 2015 Mar 13;290(11):6857-67.

112. Zhang L, Chen S, Bao N, Yang C, Ti Y, Zhou L, Zhao J. Sox4 enhances chondrogenic differentiation and proliferation of human synovium-derived stem cell via activation of long noncoding RNA DANCR. J. Mol. Histol. 2015 Dec;46(6):467-73.

113. Zhang L, Yang C, Chen S, Wang G, Shi B, Tao X, Zhou L, Zhao J. Long Noncoding RNA DANCR Is a Positive Regulator of Proliferation and Chondrogenic Differentiation in Human SynoviumDerived Stem Cells. DNA Cell Biol. 2017 Feb;36(2):136-42.

114. Barter MJ, Gomez R, Hyatt S, Cheung K, Skelton AJ, Xu Y, Clark IM, Young DA. The long noncoding RNA ROCR contributes to SOX9 expression and chondrogenic differentiation of human mesenchymal stem cells. Dev. Camb. Engl. 2017 15;144(24):4510-21.

115. Ishikawa $T$, Nishida $T$, Ono M, Takarada $T$, Nguyen HT, Kurihara S, Furumatsu $T$, Murase $\mathrm{Y}$, Takigawa M, Oohashi T, Kamioka H, Kubota S. Physiological role of urothelial cancerassociated one long noncoding RNA in human skeletogenic cell differentiation. J. Cell. Physiol. 2018 Jun;233(6):4825-40.

116. Liu Y, Li G, Zhang J. The role of long non-coding RNA H19 in musculoskeletal system: A new player in an old game. Exp. Cell Res. 2017 Nov 15;360(2):61-5.

\section{Figure legends}

Figure 1: Endochondral ossification. (A) Mesenchymal cells condensation. (B) Fetal hyaline cartilage model develops. (C) Cartilage calcifies and a periostal bone collar forms around diaphysis. 
(D) Primary ossification center forms in the diaphysis. (E) Secondary ossification center forms in epiphysis.

Figure 2: Components of cartilage. Cartilage is composed of specialized cells called chondrocytes that produce an abundant extracellur matrix. Three main protein classes are present in articular cartilage: collagens (mainly type II collagen), proteoglycans (mainly aggrecan), and non-collagenous proteins (including link protein, fibronectin and cartilage oligomeric matrix protein, COMP). Other proteoglycans are present such as decorin and biglycan.

Figure 3: miRNA biogenesis. MiRNA are transcribed by RNA poll II into primary transcripts (primiRNA). Then, pri-miRNA are cleaved into precursor miRNA (pre-miRNA) by the micro-processor complex formed by the ribonuclease DROSHA and the DNA binding protein DiGeorge syndrome critical region 8 (DGCR8). Next, the pre-miRNA are exported to the cytoplasm by Ran-GTP-dependent dsRNA-binding protein, Exportin-5. In the cytoplasm, DICER, an RNAase III-type endonuclease, cleaves pre-miRNA to produce a duplex. Finally, the guide miRNA generated by DICER is loaded onto the RNA-induced silencing complex (RISC) and consequently binds to the 3'UTR of target genes, inducing degradation or translational inhibition of the target mRNA. 
Table 1:

$\begin{array}{llll}\text { Component Genetic Cell affected } & \text { Results } & \text { References }\end{array}$

modification

\section{Histone deacetylases}

\begin{tabular}{|c|c|c|c|c|}
\hline HDAC1 & KO & All (Germline deletion) & Embryonic lethal & {$[1,2]$} \\
\hline HDAC2 & KO & All (Germline deletion) & Reduced body size (reduced vertebrae/pelvis size) & [3] \\
\hline HDAC3 & KO & All (Germline deletion) & Embryonic lethal & {$[4,5]$} \\
\hline HDAC3 & cKO & $\begin{array}{l}\text { Osteochondral lineage } \\
\text { (Osx:Cre deletion) }\end{array}$ & $\begin{array}{l}\text { Severe osteopenia due to abnormal maturation of osteoblasts. } \\
\text { Reduced body size. Cortical bone loss. Trabecular bone loss. } \\
\text { Decreased bone formation rate. Increased bone marrow adipocyte } \\
\text { differentiation }\end{array}$ & {$[6]$} \\
\hline HDAC4 & KO & All (Germline deletion) & $\begin{array}{l}\text { Premature ossification of developing bones due to ectopic and early } \\
\text { onset chondrocyte hypertrophy }\end{array}$ & {$[7]$} \\
\hline HDAC4 & $\operatorname{Tg}$ & $\begin{array}{l}\text { Chondrocytes } \\
\text { (Col2a1promoter driven) }\end{array}$ & No endochondral ossification & [7] \\
\hline HDAC5 & $\operatorname{Tg}$ & $\begin{array}{l}\text { All (antagonization of Hdac5 } \\
\text { repressor) }\end{array}$ & $\begin{array}{l}\text { Trabecular bone loss. Decreased cortical bone strength. Decreased } \\
\text { bone formation rate }\end{array}$ & [8] \\
\hline HDAC6 & KO & All (Germline deletion) & Increased trabecular bone mineral density & [9] \\
\hline HDAC7 & сікO & $\begin{array}{l}\text { Early chondrocytes } \\
\text { (tamoxifen-inducible } \\
\text { Col2a1:Cre deletion) }\end{array}$ & $\begin{array}{l}\text { Increased proliferation and } \beta \text {-catenin levels in growth plate } \\
\text { chondrocytes. Expanded proliferative zone }\end{array}$ & [10] \\
\hline HDAC8 & KO & All (Germline deletion) & Ossification defects in frontal and interparietal bones & [11] \\
\hline HDAC8 & cKO & $\begin{array}{l}\text { Pre-osteoblasts (Twist1:Cre } \\
\text { deletion) }\end{array}$ & No effect & \\
\hline HDAC8 & cKO & $\begin{array}{l}\text { Osteoblasts (Col1a1:Cre } \\
\text { deletion) }\end{array}$ & No effect & \\
\hline HDAC8 & cKO & $\begin{array}{l}\text { Chondrocytes (Col2a1:Cre } \\
\text { deletion) }\end{array}$ & No effect & \\
\hline HDAC8 & cKO & Neural crest cells & Ossification defects in frontal and interparietal bones & \\
\hline
\end{tabular}

$1,2]$

\section{]}


(Wnt1:Cre deletion)

SIRT1 KO All (Germline deletion)

SIRT6

$\mathrm{KO}$

All (Germline deletion)
Reduced body size. Cranio-facial abnormalities. Trabecular bone loss. Altered cartilage phenotype. Increased apoptotic chondrocytes and OA severity with age

Reduced body size. Defects in proliferation and hypertrophic chondrocyte differentiation

\section{Histone methyltranferases}

$\begin{aligned} & \text { ESET CKO } \text { Mesenchymal cells } \\ & \text { (Prx1:Cre deletion) }\end{aligned}$

Accelerated chondrocyte hypertrophy. Defect in long bone growth. $\quad[15,16]$ Defect in trabecular bone formation

EZH2 KO All (Germline deletion)

$\mathrm{EZH} 2 / \mathrm{EZH} 1 \quad \mathrm{cKO} \quad \mathrm{Col} 2-\mathrm{Cre} \mathrm{Ezh1}^{-/-} \mathrm{Ezh}^{\mathrm{fl} / \mathrm{fl}}$

Embryonic lethal

Decreased overall body growth and longitudinal bone growth. Insufficient growth of the rib cage and by the abnormal vertebral column. Decreased chondrocyte proliferation and hypertrophy

$\mathrm{EZH} 2$ CKO

Neural crest cells (Wnt1:Cre Defect in craniofacial bone and cartilage formation deletion)

\section{Histone demethylase}

JMJD3

$\mathrm{KO}$

All (Germline deletion)

Reduced proliferation and hypertrophy of chondrocytes. Delayed endochondral ossification

\section{miRNA process}

DICER

CKO

Chondrocytes (Col2a1:Cre deletion)

Accelerated differentiation into postmitotic hypertrophic chondrocytes. Defects in skeletal growth 


\section{References}

1 Lagger G, O'Carroll D, Rembold M, et al. Essential function of histone deacetylase 1 in proliferation control and CDK inhibitor repression. EMBO J 2002;21:2672-81. doi:10.1093/emboj/21.11.2672

2 Montgomery RL, Davis CA, Potthoff MJ, et al. Histone deacetylases 1 and 2 redundantly regulate cardiac morphogenesis, growth, and contractility. Genes Dev 2007;21:1790-802. doi:10.1101/gad.1563807

3 Zimmermann S, Kiefer F, Prudenziati M, et al. Reduced body size and decreased intestinal tumor rates in HDAC2-mutant mice. Cancer Res 2007;67:9047-54. doi:10.1158/0008-5472.CAN-07-0312

4 Bhaskara S, Chyla BJ, Amann JM, et al. Deletion of histone deacetylase 3 reveals critical roles in S phase progression and DNA damage control. Mol Cell 2008;30:61-72. doi:10.1016/j.molcel.2008.02.030

5 Montgomery RL, Potthoff MJ, Haberland M, et al. Maintenance of cardiac energy metabolism by histone deacetylase 3 in mice. J Clin Invest 2008;118:3588-97. doi:10.1172/JCI35847

6 Razidlo DF, Whitney TJ, Casper ME, et al. Histone Deacetylase 3 Depletion in Osteo/Chondroprogenitor Cells Decreases Bone Density and Increases Marrow Fat. PLoS ONE 2010;5. doi:10.1371/journal.pone.0011492

7 Vega RB, Matsuda K, Oh J, et al. Histone deacetylase 4 controls chondrocyte hypertrophy during skeletogenesis. Cell 2004;119:555-66. doi:10.1016/j.cell.2004.10.024

8 Li H, Xie H, Liu W, et al. A novel microRNA targeting HDAC5 regulates osteoblast differentiation in mice and contributes to primary osteoporosis in humans. J Clin Invest 2009;119:3666-77. doi:10.1172/JCI39832

9 Zhang Y, Kwon S, Yamaguchi T, et al. Mice lacking histone deacetylase 6 have hyperacetylated tubulin but are viable and develop normally. Mol Cell Biol 2008;28:1688-701. doi:10.1128/MCB.01154-06 
10 Bradley EW, Carpio LR, Olson EN, et al. Histone deacetylase 7 (Hdac7) suppresses chondrocyte proliferation and $\beta$-catenin activity during endochondral ossification. J Biol Chem 2015;290:118-26. doi:10.1074/jbc.M114.596247

11 Haberland M, Mokalled MH, Montgomery RL, et al. Epigenetic control of skull morphogenesis by histone deacetylase 8. Genes Dev 2009;23:1625-30. doi:10.1101/gad.1809209

12 Lemieux ME, Yang X, Jardine K, et al. The Sirt1 deacetylase modulates the insulin-like growth factor signaling pathway in mammals. Mech Ageing Dev 2005;126:1097-105. doi:10.1016/j.mad.2005.04.006

13 Gabay O, Zaal KJ, Sanchez C, et al. Sirt1-deficient mice exhibit an altered cartilage phenotype. Jt Bone Spine Rev Rhum 2013;80:613-20. doi:10.1016/j.jbspin.2013.01.001

14 Piao J, Tsuji K, Ochi H, et al. Sirt6 regulates postnatal growth plate differentiation and proliferation via Ihh signaling. Sci Rep 2013;3:3022. doi:10.1038/srep03022

15 Yang L, Lawson KA, Teteak CJ, et al. ESET histone methyltransferase is essential to hypertrophic differentiation of growth plate chondrocytes and formation of epiphyseal plates. Dev Biol 2013;380:99-110. doi:10.1016/j.ydbio.2013.04.031

16 Lawson KA, Teteak CJ, Zou J, et al. Mesenchyme-specific knockout of ESET histone methyltransferase causes ectopic hypertrophy and terminal differentiation of articular chondrocytes. J Biol Chem 2013;288:32119-25. doi:10.1074/jbc.M113.473827

17 Lui JC, Garrison P, Nguyen Q, et al. EZH1 and EZH2 promote skeletal growth by repressing inhibitors of chondrocyte proliferation and hypertrophy. Nat Commun 2016;7:13685. doi:10.1038/ncomms13685

18 Schwarz D, Varum S, Zemke M, et al. Ezh2 is required for neural crest-derived cartilage and bone formation. Dev Camb Eng/ 2014;141:867-77. doi:10.1242/dev.094342

19 Zhang F, Xu L, Xu L, et al. JMJD3 promotes chondrocyte proliferation and hypertrophy during endochondral bone formation in mice. J Mol Cell Biol 2015;7:23-34. doi:10.1093/jmcb/mjv003

20 Kobayashi T, Lu J, Cobb BS, et al. Dicer-dependent pathways regulate chondrocyte proliferation and differentiation. Proc Natl Acad Sci U S A 2008;105:1949-54. doi:10.1073/pnas.0707900105 
21 Nakamura Y, Inloes JB, Katagiri T, et al. Chondrocyte-Specific MicroRNA-140 Regulates Endochondral Bone Development and Targets Dnpep To Modulate Bone Morphogenetic Protein Signaling ${ }^{~}$. Mol Cell Biol 2011;31:3019-28. doi:10.1128/MCB.05178-11 
(D)

(C)

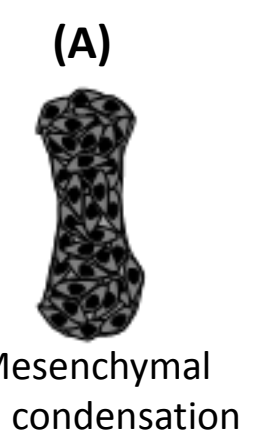

(B) Hyalin

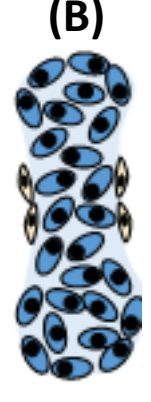
cell condensation

Calcified cartilage Bone
collar
Secondary ssification center (epiphysis)
0

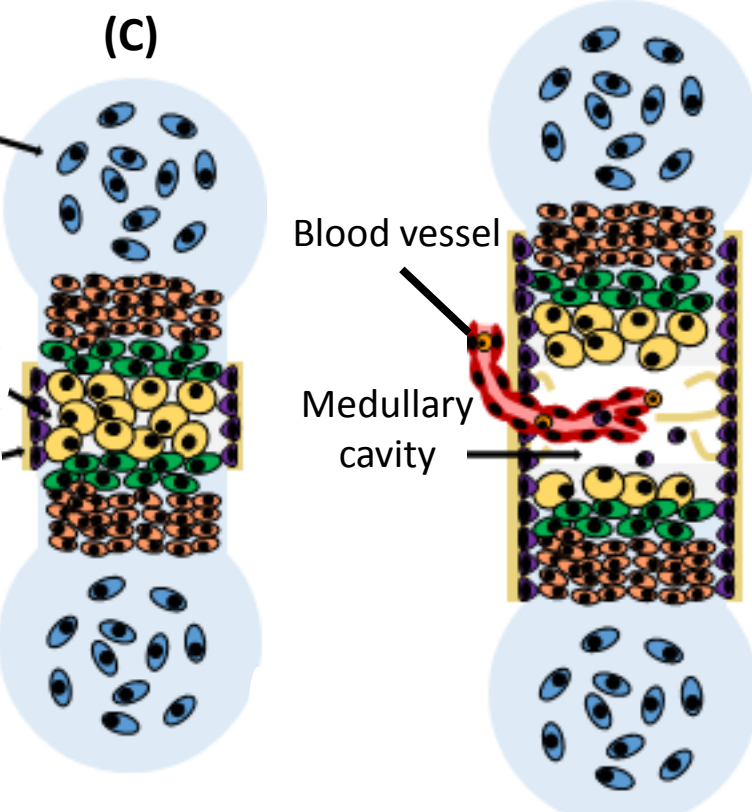

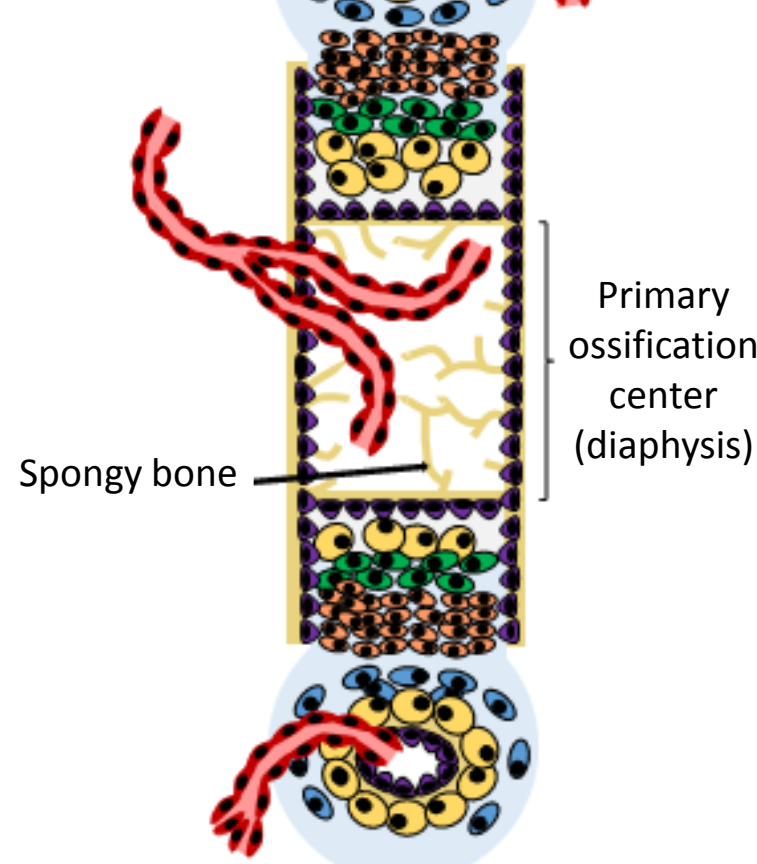

Mesenchymal cell

$\Leftrightarrow$ Perichondrial cell

- Resting chondrocytes

- Proliferating chondrocytes

- Prehypertrophic chondrocytes

- Hypertrophic chondrocytes

- Osteoblast

- Endothelial progenitor cell

- Hematopoietic progenitor cell

- Osteoprogenitor cell 


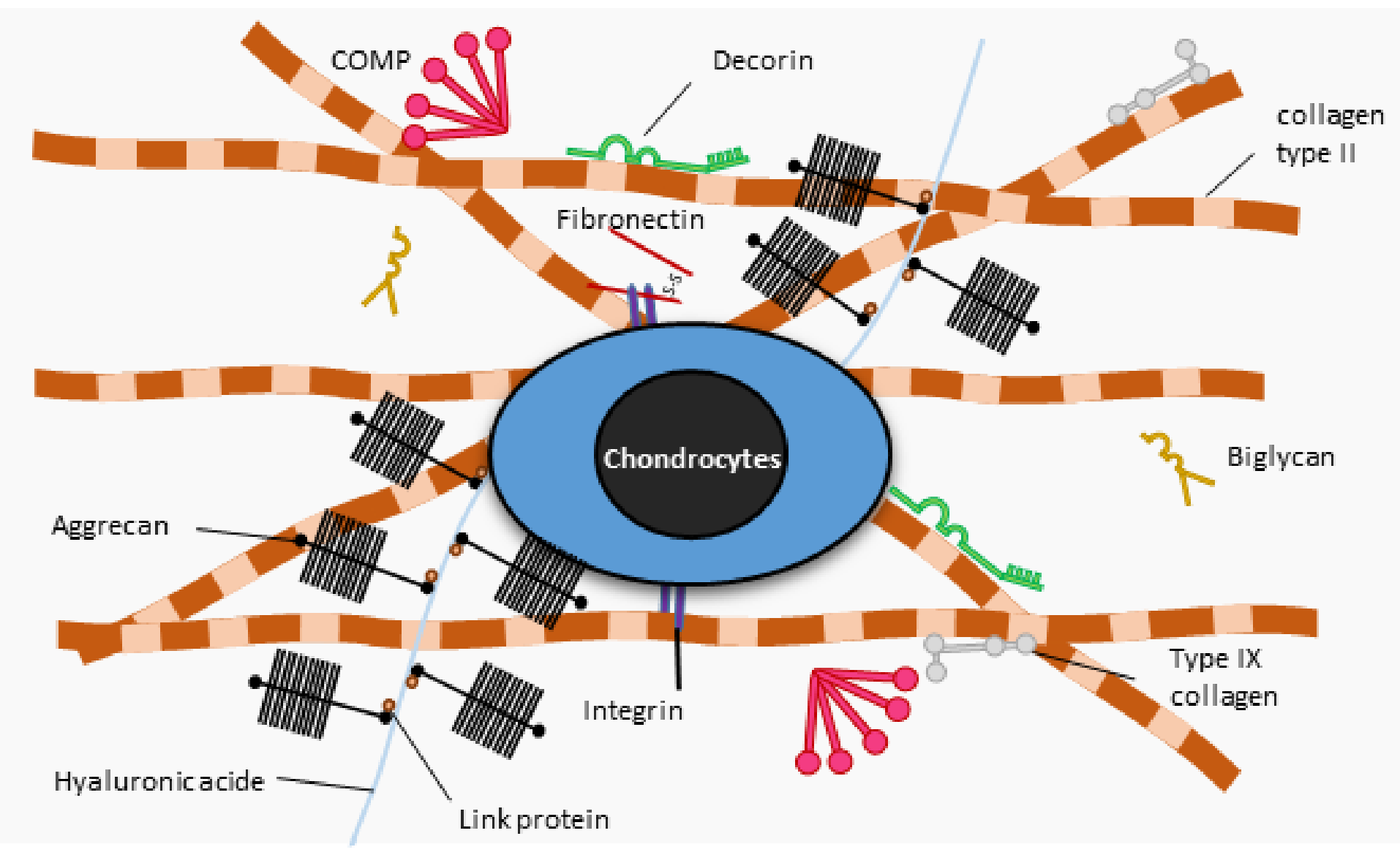

Figure 2 


\section{NUCLEUS}
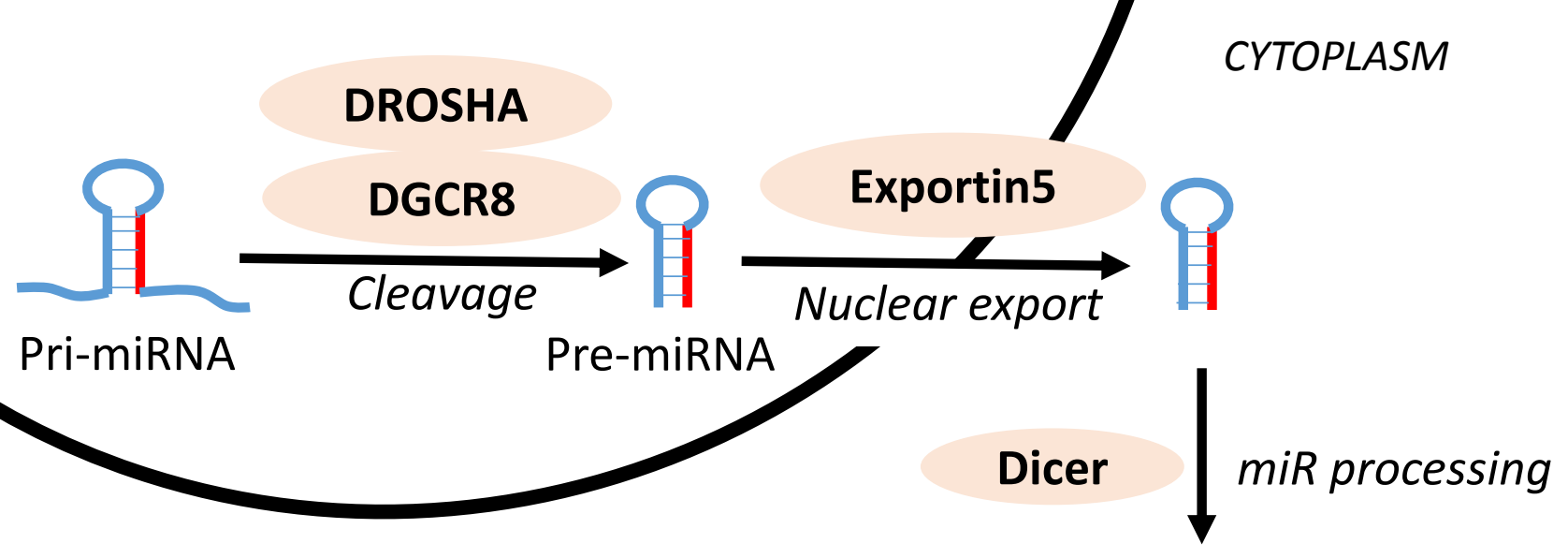

miRNA duplex

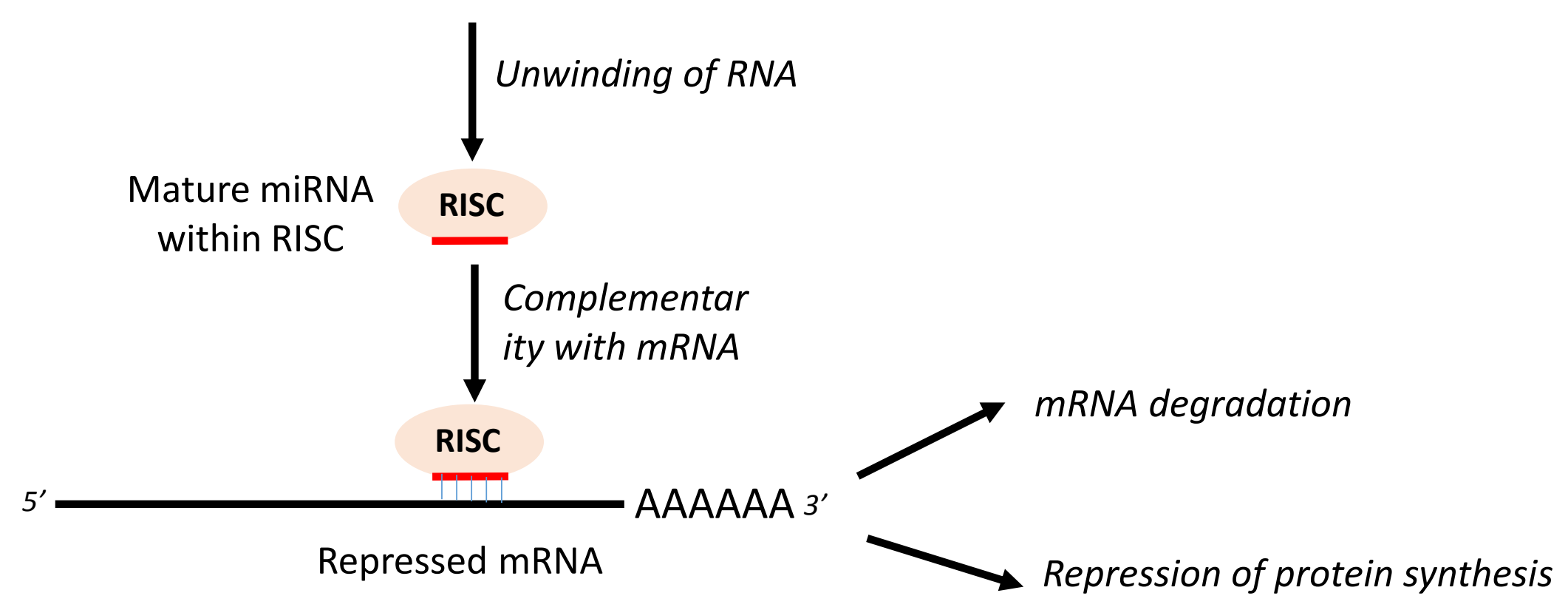

Figure 3 